\title{
35. CENOZOIC RADIOLARIANS FROM THE BRAZIL BASIN AND RIO GRANDE RISE ${ }^{1}$
}

\author{
D. A. Johnson, Woods Hole Oceanographic Institution, Woods Hole, Massachusetts
}

\begin{abstract}
The Neogene of the southwestern Atlantic is virtually barren of biogenic silica. Of the four sites drilled on Leg 72 , only two contained identifiable radiolarian specimens. In the southwestern Brazil Basin (Site 515), radiolarians are present only from the upper Oligocene (Anomaly 8, about $28 \mathrm{Ma}$ ) to the middle Miocene (Zone NN8, about $11.5 \mathrm{Ma}$ ). On the Rio Grande Rise (Site 516), radiolarians are present only within a short interval of the lower Miocene (Zones N5-N6, about 18-20 Ma). The abrupt cessation of silica deposition in the upper middle Miocene is characteristic of many drill sites in the tropical and temperate Atlantic and implies that a major oceanographic "threshold" was exceeded at this time, allowing the Atlantic waters to become either less productive or relatively silica deficient. Siliceous microfossils are notably more abundant in Oligocene-Miocene sediments of deep regions where carbonate preservation is poor (Site 515) than in equivalent carbonate-rich strata nearby (Site 516). This discrepancy suggests that the presence of calcareous microfossils may act to enhance post-depositional dissolution of biogenic silica tests by elevating the $\mathrm{pH}$ of the surrounding pore waters. Carbonate-free clays, by contrast, may provide a more favorable chemical environment for silica preservation.
\end{abstract}

\section{INTRODUCTION}

Radiolarians were identified at two of the four sites drilled on Leg 72. The localities of these sites are: Site 515 , southwestern Brazil Basin, $26^{\circ} 14.3^{\prime} \mathrm{S}, 36^{\circ} 30.2^{\prime} \mathrm{W}$, water depth $4252 \mathrm{~m}$; Site 516, Rio Grande Rise, $30^{\circ}$ $16.6^{\prime} \mathrm{S}, 35^{\circ} 17.1^{\prime} \mathrm{W}$, water depth $1313 \mathrm{~m}$. Radiolarians are absent at the other two sites (Sites 517 and 518), which were hydraulically piston cored (HPC) down into upper Neogene sediments on the western flank of the Rio Grande Rise.

After shipboard preparation and analysis of all corecatcher samples to determine the presence of radiolarians, each core within which radiolarians were identified was sampled at intervals of approximately one sample per $150-\mathrm{cm}$ section. In the intervals where core-catcher examination revealed no radiolarians, only one or two additional samples per core were prepared. Because of the high accumulation rate $(>20 \mathrm{~m} / \mathrm{Ma})$ in the radiolarian-rich interval (Hole 515B, Cores 8 to 48), we have tabulated the occurrences of radiolarians in only two or three samples per core, generally those from Sections 2, 4 , and CC (see Table 1).

Microscope slides of the carbonate-free coarse fraction were prepared according to standard techniques described by Riedel (1957) and Riedel and Sanfilippo (1977). Successful preparation of radiolarian slides required the use of repeated procedures for sample disaggregation. Radiolarian tests at Site 515 were generally obscured by clay or fecal pellet aggregates. It was only through the use of multiple steps of sonification, sieving, and rewashing that adequate quantities of radiolarians could be separated.

The primary objective of this study was to determine the occurrences at each site of radiolarian taxa previously recognized to be stratigraphically useful in tropical and subtropical assemblages. These data are discussed

${ }^{-1}$ Barker, P. F., Carlson, R. L., Johnson, D. A., et al., Init, Repts. DSDP, 72: Washington (U.S. Govt. Printing Office). and summarized in the section "Radiolarians at Each Site." Table 1 indicates species occurrences within continuously cored intervals at sites where radiolarians are sufficiently common and well preserved to allow age determination. The species lists include many of the stratigraphically useful taxa that were identified, but other taxa with diagnostic first or last appearances may also be present in some of the samples.

Some of the stratigraphic intervals that contain radiolarians may be dated independently using calcareous microfossils and/or paleomagnetic polarity reversals. Consequently, we are able to provide approximate correlations between some of the siliceous microfossil datum levels, the standard nannoplankton and foraminiferal zonations, and the paleomagnetic time scale (e.g., Lowrie and Alvarez, 1981; Berggren et al., this volume). These correlations are presented and discussed in the stratigraphic synthesis chapter for Site 516 (Berggren et al., this volume), and in the site chapter, Site 515 (this volume).

\section{CENOZOIC RADIOLARIAN ZONATION}

Extensive investigations of sediments cored on earlier legs of DSDP have led to the construction of a lowlatitude radiolarian zonation for most of the Cenozoic. The zonation scheme that will be used in this report for the post-Eocene follows that of Riedel and Sanfilippo (1971). We have incorporated the refinements recently proposed by Riedel and Sanfilippo (1978), including a finer subdivision of the former Calocycletta virginis Zone of the lower Miocene. We have not attempted to subdivide the Quaternary sediments from Leg 72 into radiolarian zones (e.g., Nigrini, 1971), because the Quaternary of the southwestern Atlantic is virtually barren of radiolarians except for a few isolated samples.

The following list identifies the post-Eocene radiolarian zones used in this study, along with the definitions of the zonal boundaries, following the recent modifications proposed by Riedel and Sanfilippo (1978). We have elected to retain the more familiar generic names 
for those taxa in the artiscin lineages that are used to define zonal boundaries (Cannartus; Ommatartus). Nevertheless, a revised classification for this lineage, including new generic names, has recently been proposed (e.g., Sanfilippo and Riedel, 1980). The zones are listed below in order from oldest to youngest, beginning with the Oligocene:

\section{Oligocene}

\section{Theocyrtis tuberosa Zone}

Base: First evolutionary appearance of Lithocyclia angustum from $L$. aristotelis.

Dorcadospyris ateuchus Zone

Base: First evolutionary appearance of $D$. ateuchus from $D$. triceros.

Lychnocanoma elongata Zone (synonymous with Lychnocanium bipes Zone)

Base: First morphotypic appearance of Lychnocanoma elongata.

\section{Miocene}

\section{Cyrtocapsella tetrapera Zone}

Base: First morphotypic appearance of $C$. tetrapera. Stichocorys delmontensis Zone

Base: Last morphotypic appearance of Theocyrtis annosa.

$S$. wolffii Zone

Base: First morphotypic appearance of $S$. wolffii. Calocycletta costata Zone

Base: First morphotypic appearance of $C$. costata. D. alata Zone

Base: First evolutionary appearance of $D$. alata. Cannartus(?) petterssoni Zone soni.

Base: First morphotypic appearance of $C$.(?) petters-

Ommatartus antepenultimus Zone

Base: First evolutionary appearance of $O$. hughesi. O. penultimus Zone

Base: Last morphotypic appearance of $O$. hughesi. $S$. peregrina Zone

Base: First evolutionary appearance of $S$. peregrina from $S$. delmontensis.

\section{Pliocene}

Spongaster pentas Zone

Base: First evolutionary appearance of $S$. pentas from $S$. berminghami.

Pterocanium prismatium Zone

Base: Last morphotypic appearance of Stichocorys peregrina.

\section{Quaternary}

\section{Unzoned}

Base: Last occurrence of $P$. prismatium.

\section{RADIOLARIANS AT EACH SITE}

In Table 1, the information on occurrences of Cenozoic radiolarians is summarized for those stratigraphic intervals in which there are identifiable radiolarians. For other intervals of the cores, radiolarian abundance is discussed in the text.

\section{Site 515, Southwestern Brazil Basin}

The continuously cored stratigraphic interval at this site represents a virtually complete depositional record from the Recent to the early Oligocene (Magnetic Anomaly 12 , about $34 \mathrm{Ma}$ ). At $618 \mathrm{~m}$ sub-bottom, Hole 515B penetrated a marked unconformity corresponding to a strong acoustic reflector, beneath which several meters of early Eocene pelagic limestones were recovered before the termination of drilling. The principal objective of Site 515 was to recover the entire sequence of sediments overlying the acoustic reflector, and to determine the age of the sediments on either side of the associated unconformity. When this objective had been achieved, drilling was terminated at this site.

\section{Pleistocene}

Cores 515A-3 and 515A-4 (sub-bottom depth $=13$ to $18 \mathrm{~m}$ ) contain diverse and well-preserved assemblages of Quaternary radiolarians. The age of this interval of the core is approximately $0.4-0.7 \mathrm{Ma}$, because the Brunhes/ Matayama boundary occurs near the base of Core 515A4 (see site chapter, Site 515 , this volume). This is the only interval of the Quaternary within which radiolarians are present. The diverse assemblage includes the following taxa (see species list for more complete bibliographic reference to each):

Collosphaera tuberosa, Spongaster tetras, Botryocyrtis scutum, Pterocorys hertwigii, Lamprocyclas maritalis polypora, Amphirhopalum ypsilon, Theocorythium trachelium, Anthrocyrtidium ophirense, Eucyrtidium hexagonatum, Disolenia zanguebarica, Lamprocyrtis nigriniae, D. quadrata, Lithopera bacca, Cornutella profunda, Didomocyrtis tetrathalamus, Euchitonia furcata, A. zanguebaricum, Pterocanium praetextum, Phormostichoartus corbula, Pterocanium trilobum, Spirocyrtis scalaris. This assemblage is comparable to that observed in modern plankton assemblages in the southwestern Atlantic (Boltovskoy and Riedel, 1980).

\section{Miocene-Oligocene}

Cores 515B-8 through 515B-48, which span the middle Miocene to upper Oligocene (about 11.5-28 Ma), contain common, well-preserved radiolarians. Above the middle Miocene, radiolarians become abruptly absent, a feature which is apparently characteristic of the tropical and temperate Atlantic (Riedel and Sanfilippo, 1970; Johnson, 1977). This radiolarian-bearing sequence grades downward to a silica-free detrital clay of Oligocene age, which extends from Core 515B-48 down to the erosional unconformity in Core 515B-56 (see site chapter, Site 515 , this volume).

Because of the diverse nature of the radiolarian assemblages in the Miocene-Oligocene interval of Site 515, the results have been summarized in tabular form (Table 1). In many instances, it is possible to designate a zonal age assignment according to the zonation of Riedel and Sanfilippo (1978) for low-latitude regions. Many of the key marker species that define zonal boundaries in low latitudes are also present at Site 515. A number of notable exceptions, however, may reflect the lower diver- 
Table 1. Radiolarians in the Oligocene-Miocene at Hole 515B.

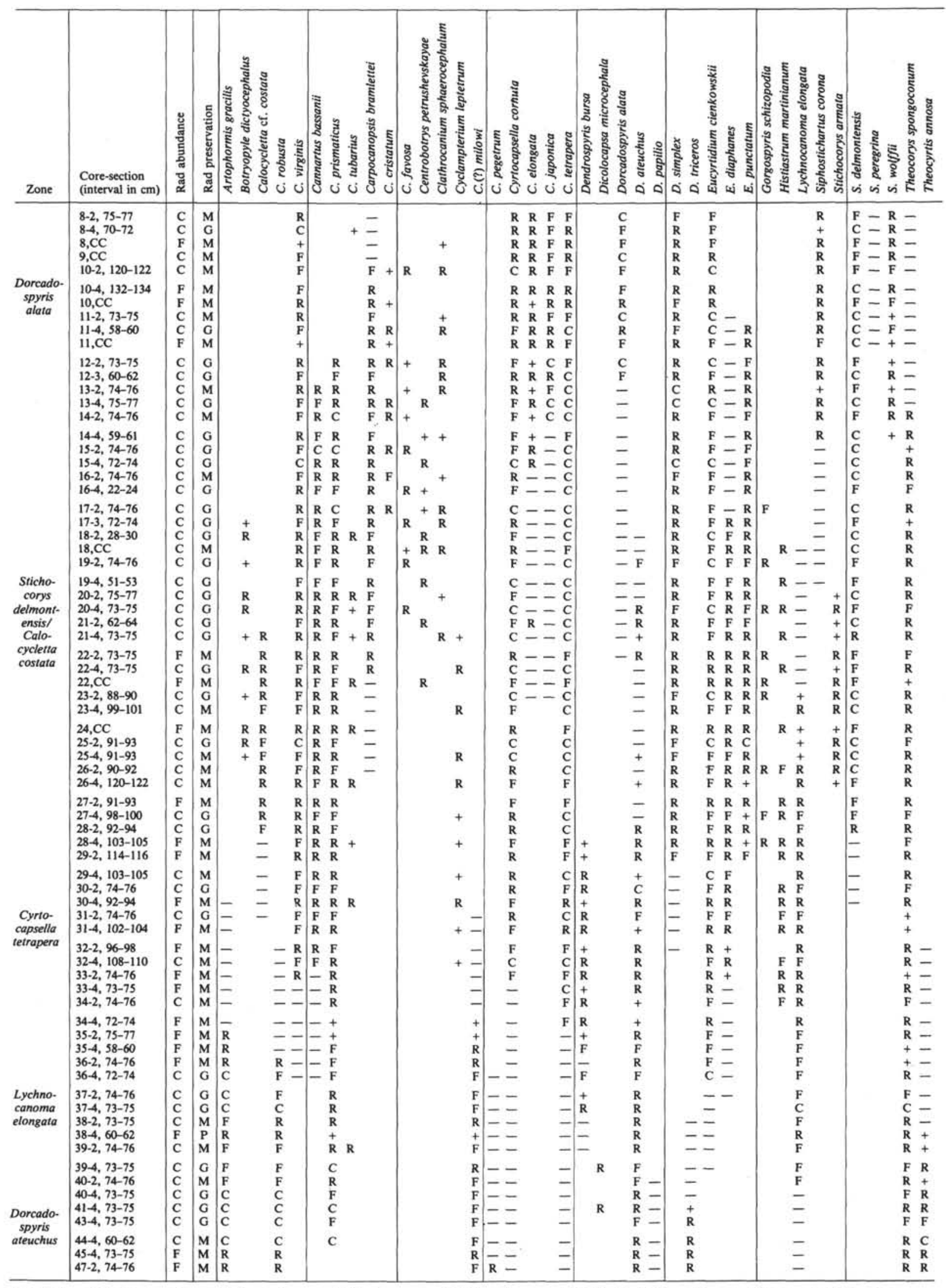

Note: $\mathbf{R a d}=$ radiolarian, $\mathrm{A}=$ abundant $(>50$ specimens per slide), $\mathrm{C}=$ common $(15-50$ specimens per slide), $\mathrm{F}=$ few $(5-15$ specimens per slide); $\mathrm{R}=\mathrm{rare}(2-5$ specimens per $\begin{aligned} & \text { slide) },+=\text { trace (only one specimen per slide), }-=\text { absent (taxon was searched for, but was not found on any of the prepared slides); } E=e x c e l l e n t, ~ \\ & \text { erate, } \mathrm{P}=\text { poor. }\end{aligned}$ 
sity of the assemblages in these middle latitudes. The Miocene-Oligocene interval of the cores is generally lacking in calcareous microfossils; thus, the only independent stratigraphic control is from paleomagnetic polarity patterns (see site chapter, Site 515 , this volume). The apparent absence of key radiolarian taxa may be an artifact of hiatuses at this site. Nevertheless, the assemblage resembles that of the Mediterranean (Sanfilippo et al., 1973) much more closely than that of equatorial latitudes (Riedel and Sanfilippo, 1971). Below are listed a number of the apparent differences between the Brazil Basin assemblages and those of lower latitudes of comparable ages (Johnson 1974; 1976; 1977).

Calocycetta. The form designated Calocycletta costa$t a$ is a zonal marker in tropical latitudes (Riedel and Sanfilippo, 1971), but is notably rare in the Brazil Ba$\sin$. Specimens at Site 515 that resemble $C$. costata are smaller and have less sharply developed longitudinal ribs than comparable forms from low latitudes. A form resembling $C$. virginis is common in the lower Miocene, but is notably smaller and less robust, and has less welldeveloped abdominal feet than the characteristic lowerlatitude forms. C. robusta is well developed in the lower Miocene and upper Oligocene, though somewhat smaller than the low-latitude equivalent.

Dorcadospyris. The zonal marker D. alata is well represented in the Brazil Basin, although in some instances the spines are poorly developed or absent entirely from the broadly divergent feet. This species apparently has a very long stratigraphic range in middle latitudes, hence the $D$. alata Zone occupies a considerable portion of Site 515 (Table 1). In the middle and lower Miocene, $D$. simplex is present, but $D$. dentata and $D$. forcipata are notably rare compared to their relative abundance in tropical latitudes. In the Oligocene, $D$. ateuchus and $D$. triceros are present, whereas $D$. papilio and $D$. circulus are absent. Thus the use of this genus for biostratigraphic age control is only of limited value in the middle latitude regions.

Cannartus and Ommatartus. Genera of the artiscin lineage are notably rare in the lower and middle Miocene of the Brazil Basin. The most common forms are C. prismaticus and C. bassanii, as in the Mediterranean region (Sanfilippo et al., 1973). Notably rare are $C$. petterssoni, $C$. laticonus, $C$. violina, and $C$. tubarius. Thus it would appear that the use of $C$. petterssoni and $O$. hughesi as zonal marker species may not be possible in middle latitudes.

Carpocanopsis. Specimens of C. bramlettei, C. cingulatum, and $C$. favosum are quite rare compared to equivalent low-latitude assemblages.

Lithopera. Several species of this genus are commonly present in low latitudes, including $L$. thornburgi, $L$. baueri, $L$. renzae, $L$. neotera, and $L$. bacca (Sanfilippo and Riedel, 1970; Johnson and Wick, 1982). In the Brazil Basin, none of these forms is consistently present in those stratigraphic intervals where they might be expected. Thus, the application of the Lithopera lineage(s) for biostratigraphy appears to be restricted to tropical latitude regions.
Stichocorys. S. delmontensis is common throughout the Miocene of the Brazil Basin, and the lower limit of this species may be synchronous with its first appearance in tropical latitudes. $S$. wolffii, however, is notably rare, and its use as a zonal marker species is perhaps not appropriate for middle latitudes. Thus we are unable to discriminate between the $S$. delmontensis, $S$. wolffii, and Calocycletta costata zones at Site 515 (Table 1) because the latter two taxa are not sufficiently abundant nor distinct to allow the designation of a zonal boundary.

Siphostichartus. The lineage from S. praecorona to $S$. corona is well represented in tropical latitudes (Nigri$\mathrm{ni}, 1977)$, but this genus is especialy rare in the Brazil Basin.

Cyrtocapsella. Specimens of $C$. cornuta and C. tetrapera are common in the Brazil Basin. C. japonica is notably rare compared to tropical latitudes (Johnson and Wick, 1982), but $C$. elongata is consistently present.

\section{Site 516, Rio Grande Rise}

Attempts to extract radiolarians from samples at this site were largely unsuccessful. Repeated procedures of soaking, sonification, and sieving left a carbonate-free residue, which consisted principally of fecal pellets, with smaller percentages of detrital mineral grains and fish debris. This result was somewhat surprising in view of the comparable oceanographic setting at Site 516 and at the previous Brazil Basin Site (515), in which radiolarians are common in the Oligocene and Miocene. It is possible that Site 516 is significantly closer to the center of the southern subtropical gyre and that biogenic sedimentation is notably less here than in the Brazil Basin. Alternatively, the virtual absence of silica from Site 516 may reflect post-depositional dissolution of biogenic silica, perhaps enhanced by the presence of calcareous microfossil tests.

Radiolarians are common and moderately well preserved within a single stratigraphic interval at Site 516, namely, the lower part of the lower Miocene (Cores 51636 through 516-40). The assemblage in these cores may be assigned to the Cyrtocapsella tetrapera Zone, based on the presence of the following taxa:

C. tetrapera, Siphostichartus praecorona, C. cornuta, Stichocorys delmontensis, Dorcadospyris ateuchus, Lychnocanoma elongata, Dicolocapsa microcephala, Theocorys spongoconum, Eucyrtidium cienkowskii, Cyclampterium(?) milowi, Cannartus bassanii, C. prismaticus.

All other intervals of Site 516 are barren of identifiable radiolarians.

\section{DISCUSSION}

Three aspects of the radiolarian assemblages in the southwestern Atlantic are noteworthy: (1) the relatively low diversity and somewhat poorer preservation of the assemblages in subtropical latitudes (Sites 515 and 516), compared with assemblages of equivalent age from equatorial latitudes (Riedel and Sanfilippo, 1971; Johnson, 1977; Riedel and Westberg, 1982); (2) the abrupt disap- 
pearance of biogenic silica during the late middle Miocene (about 11-12 Ma); (3) the notably rare occurrence of biogenic silica within carbonate-rich pelagic sediments on the Rio Grande Rise (Site 516), compared with equivalent carbonate-poor strata in the Brazil Basin nearby where silica is well preserved (Site 515).

The location of Sites 515 and 516 near the center of the South Atlantic subtropical gyre is probably responsible for the relatively low diversity and uneven preservation of the radiolarian assemblages (Table 1). Even when specimens were sufficiently complete to allow their identification, terminal abdominal segments, ornamentation, and spines were commonly missing or poorly preserved. Some samples were so corroded that only the more resistant spumellarians and a few spines were remaining in the prepared samples. In the best-preserved intervals, diversity was still notably less than in equivalent equatorial strata. The following genera, which are of particular stratigraphic importance for the low-latitude zonation (Riedel and Sanfilippo, 1978), were notably absent from the Leg 72 drill sites: Lithopera, Cannartus, Carpocanopsis, Dorcadospyris (except for $D$. alata), Phormostichoartus, Cyclampterium. In many respects, the subtropical South Atlantic assemblage (Site 515; Table 1) resembles the Mediterranean Neogene (Sanfilippo et al., 1973), but with notably poorer preservation of individual taxa.

The abrupt disappearance of biogenic silica in the upper middle Miocene has been observed previously in the tropical and subtropical Atlantic (Riedel and Sanfilippo, 1970; Foreman, 1973; Johnson, 1977). It is clear that this event is of ocean-wide significance, and represents a major shift in the productivity and/or dissolution characteristics of much of the Atlantic. It is beyond the scope of this paper to examine all the possible explanations for this event. We note that other events of global significance may have occurred at approximately the same time, including the expansion of the Antarctic ice cap (Shackleton and Kennett, 1975), an intensification of deep thermohaline current flow in the Atlantic (Blanc and Duplessy, 1982), and an intensification of flow in the Circumpolar Current (Johnson et al., 1983). It is clear that the major thermohaline current systems are inextricably linked (Johnson, 1982); thus, it is difficult to identify a single cause to account for a number of cooccurring events. The high-resolution stratigraphic HPC studies may ultimately allow us to determine whether closely occurring events really are synchronous or are perhaps unrelated.

The difference between the silica preservation record at Sites 515 and 516 is puzzling, because both sites are well within the southern subtropical gyre, and one would not expect a significant difference in primary productivity between the two areas. The difference, therefore, is probably a reflection of post-depositional processes in the two regions. The typical diagnetic reaction of biogenic silica is as follows (Kastner, 1981):

$$
\begin{gathered}
\text { Siliceous ooze } \\
\text { (opal-A) }
\end{gathered} \rightarrow \underset{\text { (opal-CT) }}{\text { Porcellanite }} \rightarrow \rightarrow \underset{\text { (chalcedomy) }}{\text { Chert }}
$$

The first stage in this diagenetic sequence, the conversion of microfossil tests to opal-CT, can occur at in situ temperatures of only $20-50^{\circ} \mathrm{C}$ (lower temperature conversion is possible in sediments more than $20 \mathrm{Ma}$ old) and in places where accumulation rates are low to moderate (Kastner, 1981). This conversion requires a solution step and reprecipitation, rather than being a solid-state transformation. Thus, the destruction of siliceous microfossil tests might occur under relatively mild diagenetic conditions, with the complete removal of morphologic evidence of radiolarian shapes.

Silica dissolution should be enhanced where nearbottom values of dissolved silica are depleted; for example, silica is relatively high within AABW compared to the overlying waters (Schink et al., 1975; Broecker et al., 1976). In addition, the dissolution of biogenic silica is greatly accelerated by increasing $\mathrm{pH}$ of the surrounding waters. Wirth and Gieskes (1979) have shown that the dissolution rate of amorphous silica increases by a factor of 360 as the $\mathrm{pH}$ of the surrounding solution is increased from 5 to 11 . Conversely, Hurd and Theyer (1975) have demonstrated that an acidic solution acts to decrease the dissolution rate of siliceous tests. One possible explanation for the absence of silica at Site 516 may involve the role of $\mathrm{pH}$ in the surrounding pore waters. The abundant calcareous microfossils in the sediments at Site 516 should act to raise the $\mathrm{pH}$ of the associated pore waters, thus enhancing the dissolution of the co-occurring silica and accounting for the virtual absence of silica on the Rio Grande Rise.

\section{LIST OF SPECIES}

The purpose of this listing is to provide bibliographic references to the taxa mentioned in this report and in the accompanying tables. When the published literature contains several different concepts of the limits of a species, the reference cited conforms to the concept as applied here. For each species, at least one recent reference is given that contains appropriate species descriptions and illustrations, thereby enabling the reader to determine the criteria that have been applied in identifying the taxa in this report.

Amphirhopalum ypsilon Haeckel, 1887, p. 522; Nigrini, 1967, p. 35, pl. 3, fig. 3a-d; Nigrini, 1971, pl. 34.1, figs. 7a-c.

Anthocyrtidium ophirense (Ehrenberg), Nigrini, 1967, p. 56, pl. 6, fig. 3.

A. zanguebaricum (Ehrenberg), Nigrini, 1967, p. 58, pl. 6, fig. 4.

Artophormis gracilis Riedel, 1959, p. 300, pl. 2, figs. 12-13; Riedel and Sanfilippo, 1970, p. 532, pl. 13, figs. 6-7.

Botryocyrtis scutum (Harting), Nigrini and Moore, 1979, p. N105, pl. 28 , figs. 1a-b.

Botryopyle dictyocephalus Haeckel group. Riedel and Sanfilippo, 1971 , p. 1602, pl. 1J, figs. 21-26.

Botryostrobus auritus-B. australis (Ehrenberg) group, Nigrini, 1977, p. 246-248, pl. 1 , figs. 2-5.

Calocycletta acanthocephala (Ehrenberg), Petrushevskaya and Kozlova, 1972 , p. 544 , pl. 35 , figs. 5-7.

C. robusta Moore, 1971 , p. 743 , pl. 10, fig. 5, 6; 1972 , p. 148 , pl. 1 , fig. 6; Riedel and Sanfilippo, 1978, p. 66, pl. 3, figs. 10-11.

C. virginis (Haeckel), Riedel and Sanfilippo, 1970, p. 535, pl. 14, fig. 10; Moore, 1972, p. 147, pl. 1, fig. 7; Riedel and Sanfilippo, 1978, p. 66 , pl. 3 , figs. $13-14$.

Cannartus bassanii (Carnevale), Sanfilippo et al., 1973, p. 216, pl. 1, fig. 1-3; Sachs and Hasson, 1979, p. 1118, fig. 3C.

C. laticonus Riedel, 1959, p. 291, pl. 1, fig. 5; Riedel and Sanfilippo, 1971, pl. 1C, fig. 13.

C. prismaticus (Haeckel), Riedel and Sanfilippo, 1970, p. 520, pl. 15, fig. $1 ; 1971$, p. 1588, pl. 2C, figs. 11-13. 
C. tubarius (Haeckel), Riedel and Sanfilippo, 1970, p. 520, pl. 15, fig. 2; Kling, 1971, pl. 3, fig. 3.

C. violina Haeckel, 1887, p. 358; Riedel, 1959, p. 290, pl. 1, fig. 3; Moore, 1971, pl. 12, fig. 4.

Carpocanopsis bramlettei Reidel and Sanfilippo, 1971, p. 1597, pl. 2G, figs. 8-14, pl. 8, fig. $7 ; 1978$, p. 67 , pl. 4 , fig. 6 .

C. cristatum (Carnevale)? Riedel and Sanfilippo, 1971, p. 1957, pl. $1 \mathrm{G}$, fig. 16; pl. 2G, figs. 1-7.

C. favosa (Haeckel), Riedel and Sanfilippo, 1971, p. 1957, pl. 2G, figs. 15-16; pl. 8, figs. 9-11.

Centrobotrys petrushevskayae Sanfilippo and Riedel, 1973, p. 532, pl. 36, figs. 12-13.

Clathrocanium sphaerocephalum Haeckel. Sanfilippo et al., 1973, pl. 4 , fig. 9.

Collosphaera tuberosa Haeckel. Nigrini, 1971, p. 445, pl. 34.1, fig. 1; Knoll and Johnson, 1975, p. 63, pl. 2, figs. 1-3.

Cornutella profunda Ehrenberg. Nigrini, 1967, p. 60, pl. 6, figs. 5a-c. Cyclampterium(?) leptetrum Sanfilippo and Riedel, 1970, p. 456, pl. 2, figs. 11-12; Riedel and Sanfilippo, 1971, pl. 2D, figs. 9-12.

C.(?) milowi Riedel and Sanfilippo, 1971, p. 1593, pl. 3B, fig. 3; pl. 7, figs. 8-9; Sanfilippo et al., 1973, p. 220, pl. 4, figs. 12-14.

C.(?) pegetrum Sanfilippo and Riedel, 1970 , p. 456, pl. 2, figs. 8-310; Riedel and Sanfilippo, 1971, pl. 2D, figs. 13-14; pl. 3B, figs. 1-2.

Cyrtocapsella cornuta Haeckel. Sanfilippo and Riedel, 1970, p. 453, pl. 1, figs. 19-20; Sanfilippo et al., 1973, pl. 5, figs. 1-2.

C. elongata (Nakaseko), Sanfilippo and Riedel, 1970, p. 452, pl. 1, figs. 11-12.

C. japonica (Nakaseko), Sanfilippo and Riedel, 1970, p. 452, pl. 1, figs. 13-15; Sanfilippo et al., 1973, pl. 5, fig. 3.

C. tetrapera Haeckel. Sanfilippo and Riedel, 1970, p. 453, pl. 1, figs. 16-18; Sanfilippo et al., 1973, pl. 5, figs. 4-6.

Dendrospyris bursa Sanfilippo and Riedel, Sanfilippo et al., 1973, p. 217, pl. 2, figs. 9-13.

Dicolocapsa microcephala Haeckel, 1887, p. 1312; Sanfilippo and Riedel, 1970, pl. 1, fig. 7.

Didymocyrtis tetrathalamus (Haeckel), Riedel and Sanfilippo, 1971, p. 1588, pl. 1C, figs. 5-7; 1978, fig. 1; Sanfilippo and Riedel, 1980, fig. 1.

Disolenia quadrata (Ehrenberg), Nigrini, 1967, p. 19, pl. 1, fig. 5.

D. zanguebarica (Ehrenberg), Nigrini, 1967, p. 20, pl. 1, fig. 6 .

Dorcadospyris alata (Riedel), Riedel and Sanfilippo, 1970, pl. 14, fig. 5; 1971, pl. 2D, fig. 1; Moore, 1971, pl. 11, figs. 3-4.

D. ateuchus (Ehrenberg), Riedel and Sanfilippo, 1970, pl. 15, fig. 4; 1971 , p. 1590 , pl. 2D, fig. 6, pl. 3A, figs. 9-10; 1978, p. 68, pl. 5, fig. 3 .

D. dentata Haeckel, 1887, p. 1037; Riedel, 1957, p. 79, pl. 1, fig. 3.

D. forcipata (Haeckel), Moore, 1971, p. 740, pl. 10, figs. 1-2.

D. papilio (Riedel), Riedel and Sanfilippo, 1970, p. 523, pl. 15, fig. 5; Moore, 1971, p. 739, pl. 8, figs. 6-7.

D. simplex (Riedel), Riedel and Sanfilippo, 1970, pl. 15, fig. 6.

D. triceros (Ehrenberg), Moore, 1971, p. 739, pl. 6, figs. 1-3.

Euchitonia furcata Ehrenberg. Nigrini and Moore, 1979, p. 585, pl. 11 , figs. $2 a-b$.

Eucyrtidium acuminatum (Ehrenberg), Nigrini, 1967, p. 81, pl. 8, figs. 3a-b.

E. cienkowskii Haeckel, 1887, p. 1493; Sanfilippo et al., 1973, p. 221, pl. 5, figs. 7-11.

E. diaphanes Sanfilippo and Riedel; Sanfilippo et al., 1973, p. 221, pl. 5, figs. 12-14.

E. hexagonatum Haeckel. Nigrini, 1967, p. 83, pl. 8, figs. 4a-b.

E. punctatum (Ehrenberg) group, Sanfilippo et al., 1973, p. 221, pl. 5, figs. 15-16.

Gorgospyris schizopodia Haeckel, 1887, p. 1071, pl. 87, fig. 4; Sanfilippo et al., 1973, p. 218, pl. 3, figs. 6-7.

Histiastrum martinianum Carnevale group. Sanfilippo et al., 1973, p. 217 , pl. 2, figs. $7-8$.

Lamprocyclas maritalis maritalis Haeckel. Nigrini, 1967, p. 74, pl. 7, fig. 5.

L. maritalis polypora Nigrini, 1967, p. 76, pl. 7, fig. 6 .

Lamprocyrtis nigriniae (Caulet), Nigrini and Moore, 1979, p. N81N82, pl. 25, fig. 7.

Lithopera bacca Ehrenberg. Nigrini, 1967, p. 54, pl. 6, fig. 2; Sanfilippo and Riedel, 1970, p. 455, pl. 1, fig. 29.

L. neotera Sanfilippo and Riedel, 1970, p. 454, pl. 1, figs. 24-26, 28.

L. renzae Sanfilippo and Riedel, 1970, p. 454, pl. 1, figs. 21-23, 27
L. thornburgi Sanfilippo and Riedel, 1970, p. 455, pl. 2, figs. 4-6. Lychnocanoma elongata (Vinassa), Sanfilippo et al., 1973, p. 221, pl. 5, figs. 19-20; Riedel and Sanfilippo, 1978, p. 70, pl. 7, fig. 4.

Phormostichoartus corbula (Harting), Nigrini, 1977, p. 252, pl. 1, fig. 10.

P. doliolum (Riedel and Sanfilippo), Nigrini, 1977, p. 252-253, pl. 1, fig. 14.

Pterocanium praetextum (Ehrenberg), Riedel, 1957, p. 86, pl. 3, figs. 1-3; Moore, 1971, pl. 13, fig. 3.

Pterocanium trilobum (Haeckel), Nigrini, 1967, p. 71, pl. 7, figs. 3a-b. Pterocorys hertwigii (Haeckel), Riedel and Sanfilippo, 1978, p. 72, pl. 9, fig. 2.

Siphostichartus corona (Haeckel), Nigrini, 1977, p. 257, pl. 2, figs. 5-6.

Spirocyrtis scalaris Haeckel, 1887, p. 1509, pl. 76, fig. 14; Nigrini, 1977 , p. 259 , pl. 2 , figs. $12-13$.

Spongaster tetras Ehrenberg. Nigrini, 1967, p. 41, pl. 5, figs. 1a-b, 2; Riedel and Sanfilippo, 1978, p. 74, pl. 2, figs. 2-3.

Stichocorys armata (Haeckel), Riedel and Sanfilippo, 1971, p. 5195, pl. 2E, figs. 13-15; Sanfilippo et al., 1973, p. 222, pl. 6, figs. 1-2.

S. delmontensis (Campbell and Clark), Sanfilippo and Riedel, 1970, p. 451, pl. 1, fig. 9; Riedel and Sanfilippo, 1971, pl. 1F, figs. 5-7; pl. $2 \mathrm{E}$, figs. $10-11$.

S. peregrina (Riedel), Riedel and Sanfilippo, 1970, p. 530; 1971, pl. 8, fig. 5 .

S. wolffii Haeckel, 1887, p. 1479; Riedel, 1957, p. 92, pl. 4, figs. 6-7; Riedel and Sanfilippo, 1971, pl. 2E, figs. 8-9; 1978, p. 74, pl. 9, fig. 12.

Theocampe pirum (Ehrenberg), Riedel and Sanfilippo, 1971, p. 1601, pl. 3E, figs. 10-11; Foreman, 1973, pl. 9, figs. 11-12.

Theocorys spongoconum Kling, 1971, p. 1087, pl. 5, fig. 6; Riedel and Sanfilippo, 1971, pl. 2F, fig. 4, pl. 3C, fig. 3; 1978, p. 76, pl. 9, fig. 16.

Theocorythium trachelium (Ehrenberg), Nigrini, 1967, p. 79, pl. 8, fig. 2; Riedel and Sanfilippo, 1978, p. 76, pl. 9, fig. 17.

T. vetulum Nigrini, 1971, p. 447, pl. 34.1, figs. 6a-b; Riedel and Sanfilippo, 1978, p. 76, pl. 9, fig. 18.

Theocyrtis annosa (Riedel), Riedel and Sanfilippo, 1970, p. 535, pl. 15 , fig. $9 ; 1978$, p. 78 , pl. 10 , fig. 3.

T. tuberosa Riedel, 1959, p. 258, pl. 2, figs. 10-11; Moore, 1971, p. 743, pl. 5, figs. 5-6; Riedel and Sanfilippo, 1978, p. 78, pl. 1, fig. 11.

\section{ACKNOWLEDGMENTS}

I thank the DSDP curatorial staff at Lamont-Doherty Geological Observatory for supplying samples. D. J. Keith assisted in sample preparation. W. R. Riedel, A. Sanfilippo, and C. Nigrini contributed useful discussion and assistance in the identification of several radiolarian specimens. Financial support for this investigation was provided under NSF Grant OCE80-25208. B. Corliss and W. Berggren critically reviewed the manuscript. This is Woods Hole Oceanographic Institution Contribution No. 5235 .

\section{REFERENCES}

Blanc, P.-L., and Duplessy, J.-C., 1982. The deep water circulation during the Neogene and the impact of the Messinian salinity crisis. Deep-Sea Res., 29:1391-1414.

Boltovskoy, D., and Riedel, W. R., 1980. Polycystine Radiolaria from the southwestern Atlantic Ocean plankton. Rev. Esp. Micropaleontol., 12:99-146.

Broecker, W. S., Takahashi, T., and Li., Y.-H., 1976. Hydrography of the central Atlantic-I: the two degree discontinuity. Deep-Sea Res., 23:1083-1104.

Foreman, H. P., 1973. Radiolaria of Leg 10 with systematics and ranges for the families Amphipyndacidae, Artostrobiidae, and Theoperidae. In Worzel, J. L., Bryant, W., et al., Init. Repts. DSDP, 10: Washington (U.S. Govt. Printing Office), 407-474.

Haeckel, E., 1887. Report on the radiolaria collected by H.M.S. Challenger during the years 1873-1876. Report on the Scientific Results of the Voyage of the H.M.S. Challenger during 1873-1876: Zoology, 18: London (Eyre and Spottiswood), 1-1303.

Hurd, D. C., and Theyer, F., 1975. Changes in the physical and chemical properties of biogenic silica from the central equatorial Pacific. I. Solubility, specific surface area, and solution rate constants of acid-cleaned samples. Adv. Chem. Ser., 147:211-230. 
Johnson, D. A., 1974. Radiolaria from the eastern Indian Ocean, DSDP Leg 22. In von der Borch, C. C., Sclater, J. G., et al., Init. Repts. DSDP, 22: Washington (U.S. Govt. Printing Office), 521-575.

1976. Cenozoic radiolarians from the central Pacific, DSDP Leg 33. In Schlanger, S. O., Jackson, E. D., et al., Init. Repts. DSDP, 33: Washington (U.S. Govt. Printing Office), 425-437.

1978. Cenozoic radiolaria from the eastern tropical Atlantic, DSDP Leg 41. In Lancelot, Y., Seibold, E., et al., Init. Repts. DSDP, 41: Washington (U.S. Govt. Printing Office), 763-789.

1982. Abyssal teleconnections: interactive dynamics of the deep ocean circulation. Palaeogeogr. Palaeoclimatol. Palaeoecol., 38:93-128.

Johnson, D. A., Ledbetter, M. T., and Damuth, J. E., 1983. Neogene sedimentation and erosion in the Amirante Passage, western Indian Ocean. Deep-Sea Res., 30:195-219.

Johnson, D. A., and Wick, B., 1982. Precision of correlation of radiolarian datum levels in the Middle Miocene, equatorial Pacific. Micropaleontology, 28:43-58.

Kastner, M., 1981. Authigenic silicates in deep-sea sediments: formation and diagenesis. In Emiliani, C. (Ed.), The Sea (Vol. 7): The Oceanic Lithosphere: New York (Wiley-Interscience), 915-980.

Kling, S. A., 1971. Radiolaria: Leg 6 of the Deep Sea Drilling Project. In Fischer, A. G., Heezen, B. C., et al., Init. Repts. DSDP, 6: Washington (U.S. Govt. Printing Office), 1069-1117.

Knoll, A. H., and Johnson, D. A., 1975. Late Pleistocene evolution of the collosphaeriid Buccinosphaera invaginata Haeckel. Micropaleontology, 21:60-68.

Lowrie, W., and Alvarez, W., 1981. One hundred million years of geomagnetic polarity history. Geology, 9:392-397.

Moore, T. C., 1971. Radiolaria. In Tracey, J. I., Jr., Sutton, G. H., et al., Init. Repts. DSDP, 8: Washington (U.S. Govt. Printing Office), 727-775.

1972. Mid-Tertiary evolution of the radiolarian genus $\mathrm{Ca}$ locycletta. Micropaleontology, 18:144-152.

Nigrini, C. A., 1967. Radiolaria in pelagic sediments from the Indian and Atlantic Oceans. Scripps Inst. Oceanogr. Bull., 11:1-106. , 1971. Radiolarian zones in the Quarternary of the equatorial Pacific Ocean. In Funnell, B. M., and Riedel, W. R., (Eds.), The Micropaleontology of Oceans: New York (Cambridge University Press), pp. 443-461.

1974. Cenozoic Radiolaria from the Arabian Sea, DSDP Leg 23. In Davies, T. A., Luyendyk, B. P., et al., Init. Repts. DSDP, 26: Washington (U.S. Govt. Printing Office), 1051-1072. 1977. Tropical Cenozoic Artostrobiidae (Radiolaria). Micropaleontology, 23:241-269.

Nigrini, C., and Moore, T. C., Jr., 1979. A guide to modern Radiolaria. Spec. Publ. Cushman Found, Foraminiferal Res., No. 16.

Petrushevskaya, M. G., and Kozlova, G. E., 1972. Radiolaria: Leg 14, Deep Sea Drilling Project. In Hayes, D. E., Pimm, A. C., et al., Init. Repts. DSDP, 14: Washington (U.S. Govt. Printing Office), 495-648.

Riedel, W. R., 1953. Mesozoic and Late Tertiary Radiolaria of Rotti. J. Paleontol., 27:805-813.
1957. Radiolaria: a preliminary stratigraphy. Rep. Swed. Deep-Sea Exped., 6:61-96.

1959. Oligocene and lower Miocene Radiolaria in tropical Pacific sediments. Micropaleontology, 5:285-302.

Riedel, W. R., and Foreman, H. P., 1961. Type specimens of North American Paleozoic Radiolaria. J. Paleontol. 35:628-632.

Riedel, W. R., and Sanfilippo, A., 1970. Radiolaria, Leg 4, Deep Sea Drilling Project. In Badar, R. G., Gerard, R. D., et al., Init. Repts. DSDP, 4: Washington (U.S. Govt. Printing Office), 503-575.

1971. Cenozoic Radiolaria from the western tropical Pacific, Leg 7. In Winterer, E. L., Riedel, W. R., et al., Init. Repts. $D S D P, 7$, Pt. 2: Washington (U.S. Govt. Printing Office), 1529-1672.

1977. Cenozoic Radiolaria. In Ramsay, A. T. S. (Ed.), Oceanic Micropaleontology: New York (Academic Press), pp. 847-912. 1978. Stratigraphy and evolution of tropical Cenozoic radiolarians. Micropaleontology, 24:61-96.

Riedel, W. R., and Westberg, M. J., 1982. Neogene radiolarians from the eastern tropical Pacific and Caribbean, DSDP Leg 68. In Prell, W. L., Gardner, J. V., et al., Init. Repts. DSDP, 68: Washington (U.S. Govt. Printing Office), 289-301.

Sachs, H. M., and Hasson, P. F., 1979. Comparison of species vs. character description for very high resolution biostratigraphy using Cannartid radiolarians. J. Paleontol., 53:1112-1120.

Sanfilippo, A., Burckle, L. H., Martini, E., and Riedel, W. R., 1973. Radiolarians, diatoms, silicoflagellates and calcareous nannofossils in the Mediterranean Neogene. Micropaleontology, 19:205-234.

Sanfilippo, A., and Riedel, W. R., 1970. Post-Eocene 'closed' theoperid radiolarians. Micropaleontology, 16:446-462.

1973. Cenozoic Radiolaria (exclusive of theorperids, artostrobiids and amphipyndacids) from the Gulf of Mexico, Deep Sea Drilling Project, Leg 10. In Worzel, J. L., Bryant, W., et al., Init. Repts. DSDP, 10: Washington (U.S. Govt. Printing Office), 475-611.

1974. Radiolaria from the west central Indian Ocean and Arabian Sea, DSDP Leg 24. In Fisher, R. L., Bunce, E. T., et al., Init. Repts. DSDP, 24: Washington (U.S. Govt. Printing Office), 997-1035.

1980. A revised generic and suprageneric classification of artiscins (Radiolaria). J. Paleontol., 54:1008-1012.

Schink, D. R., Guinasso, N. L., Jr., and Fanning, K. A., 1975. Processes affecting the concentration of silica at the sediment-water interface of the Atlantic Ocean. J. Geophys. Res., 80:3013-3030.

Shackleton, N. J., and Kennett, J. P., 1975. Paleotemperature history of the Cenozoic and the initiation of Antarctic glaciation: oxygen and carbon isotope analyses in DSDP Sites 277,279 , and 281. In Kennett, J. P., Houtz, R. E., et al., Init. Repts. DSDP, 29: Washington (U.S. Govt. Printing Office), 743-755.

Wirth, G. S., and Gieskes, J. M., 1979. The initial kinetics of the dissolution of vitreous silica in aqueous media. J. Colloid Interface Sci., 68:492-500.

Date of Initial Receipt: August 20, 1982 


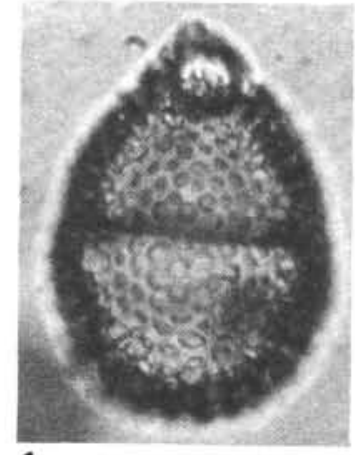

1

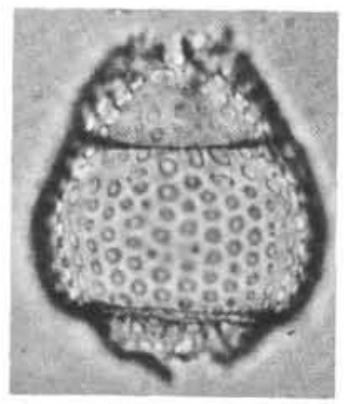

6

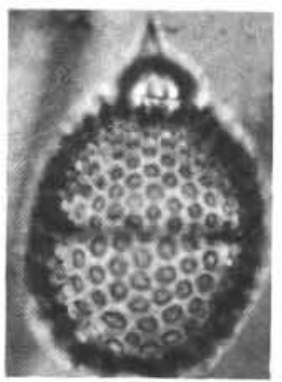

2

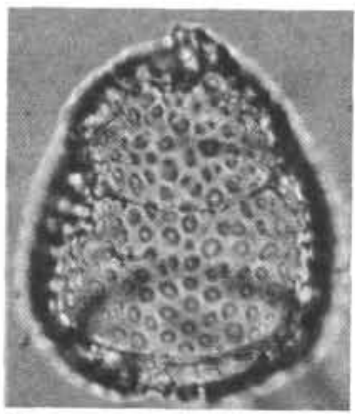

7

3
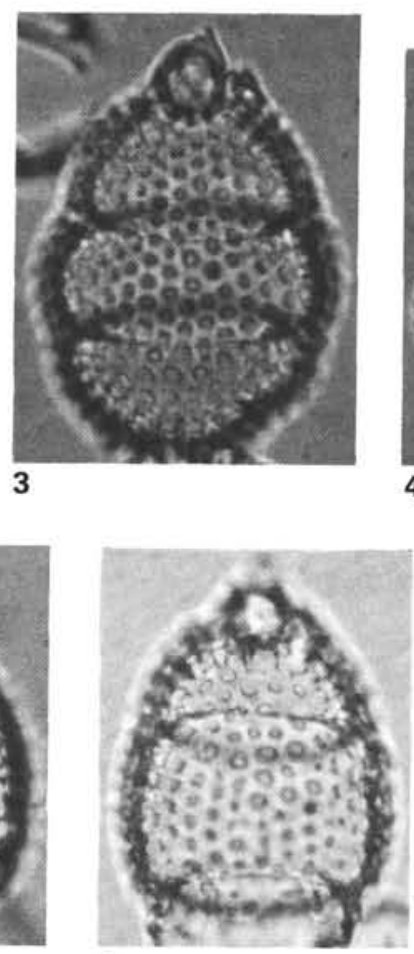

8

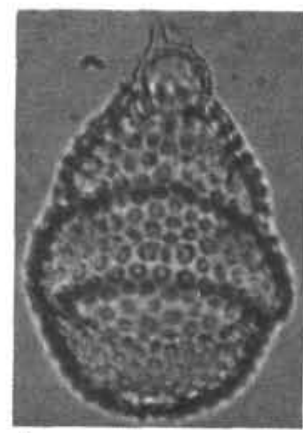

4

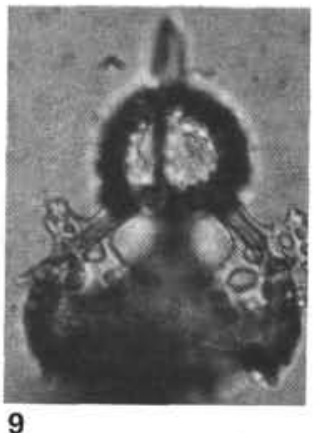

9

5
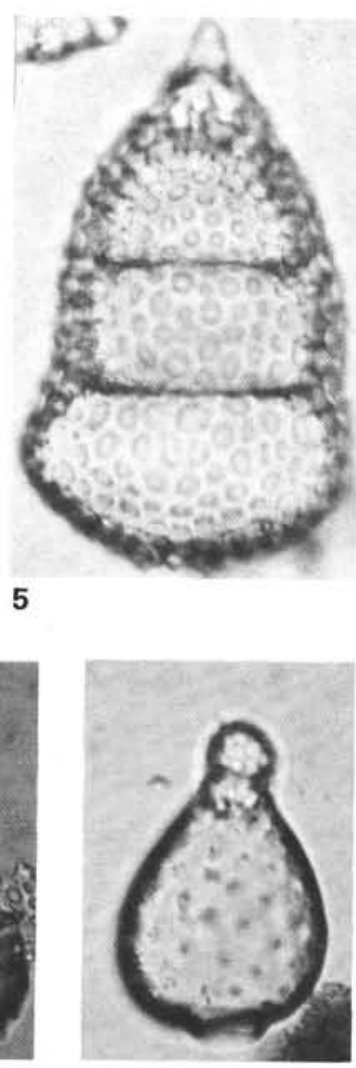

10

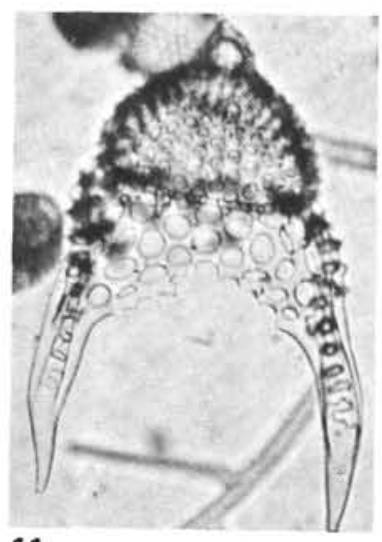

11

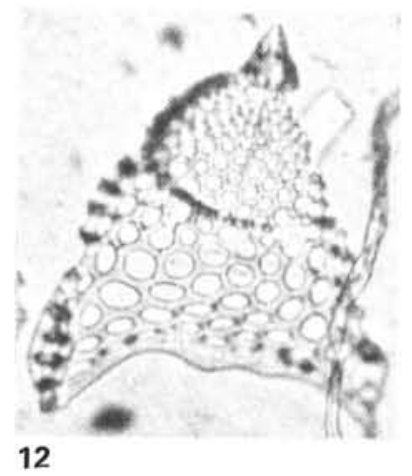

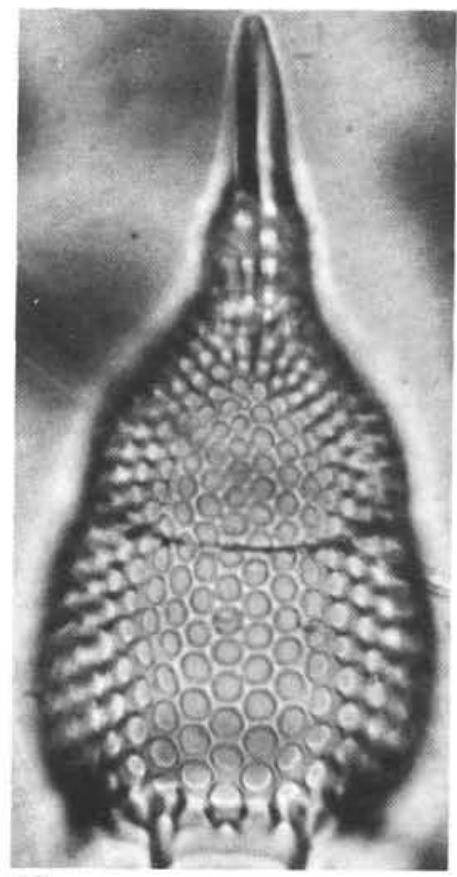

13

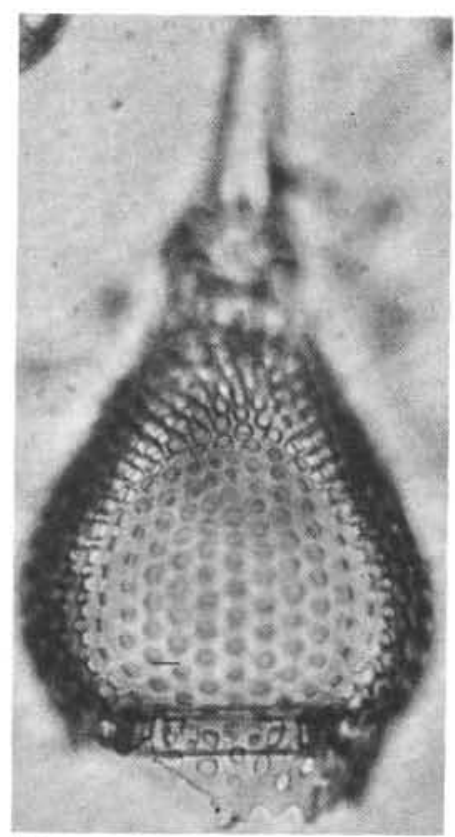

14

Plate 1. For Plates 1 and 2, the figure captions include the slide number and the location of the illustrated specimen on the slide. For an explanation of location numbers ("England Finder Coordinates"), see Riedel and Foreman, 1961. All specimens are magnified $\times 200$, unless otherwise specified. 1, 14. Sample 515B-14-2, 74-76 cm, (1) Cyrtocapsella japonica, Sl. B, O31/2, (14) Theocyrtis sp., Sl. A, M42/3. 2. C. elongata, Sample 515B-8, CC, Sl. B, J49/1. 3-4. C. tetrapera, Sample 515B-10-4, 132-134 cm, Sl. A, (3) S55/0, (4) L49/0. 5. Cyrtocapsella sp. cf. C. tetrapera, Sample 515B-21-4, 73-75 cm, SI. A, X55/0. 6-8. Theoperid, gen. et sp. indet., Sample 515B-8-4, 70-72 cm, S1. A, (6) X49/4, (8) K25/4. 7. Theoperid, gen et sp. indet., Sample 515B-11-4, 58-60 cm, Sl. A, W55/4. 9-10, 13. Sample 515B-12,CC, (9) Clathrocanium sphaerocephalum, Sl. A, Y29/0, (10) Dicolocapsa microcephala, Sl. B, 030/0, (13) Lamprocyclas sp., Sl. A, Z26/2. 11-12. Cyclampterium? milowi, Sample 515B-43-4, 73-75 cm, $\times 80$ Sl. A, (11) D29/3, (12) N42/3. 

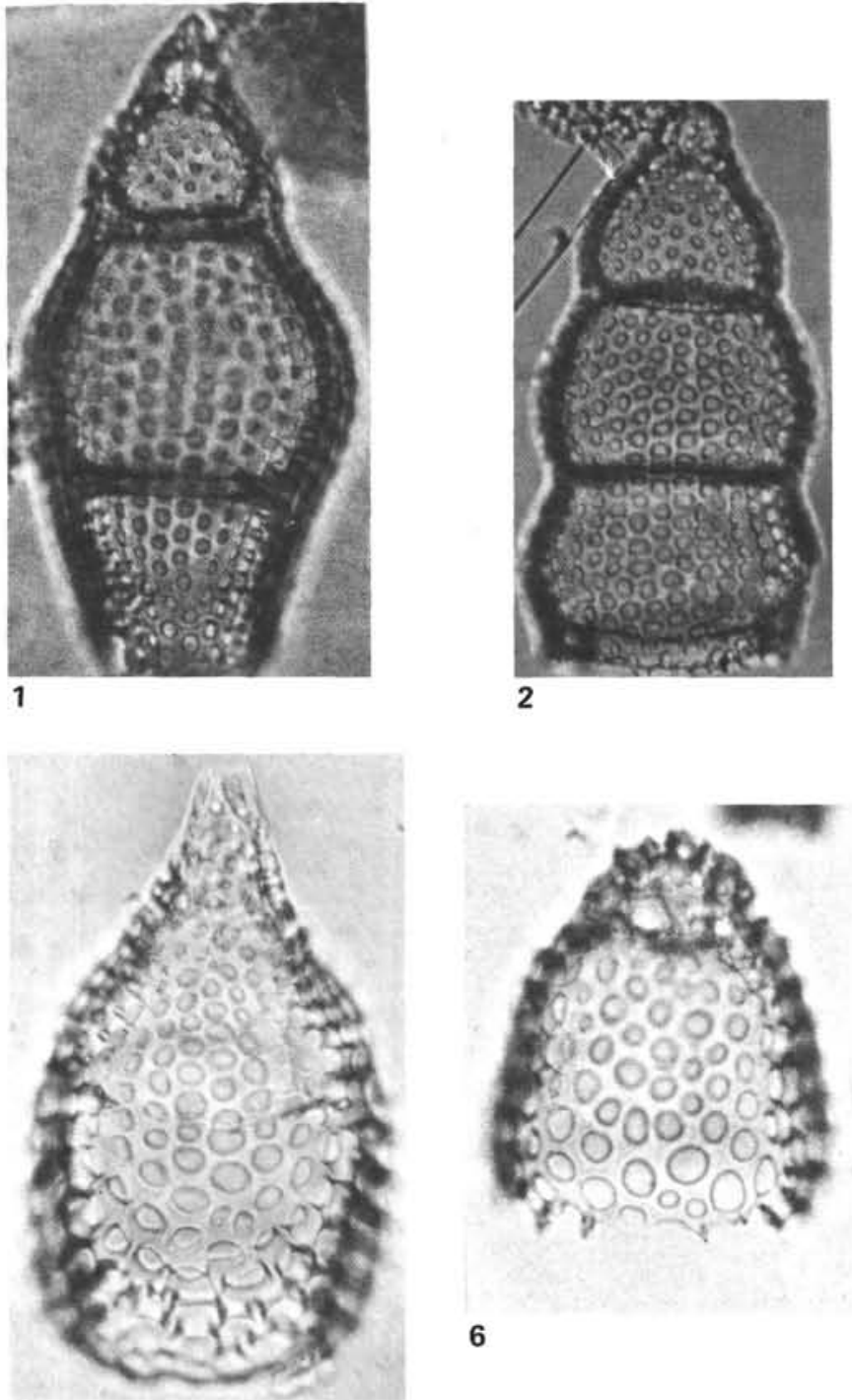

6
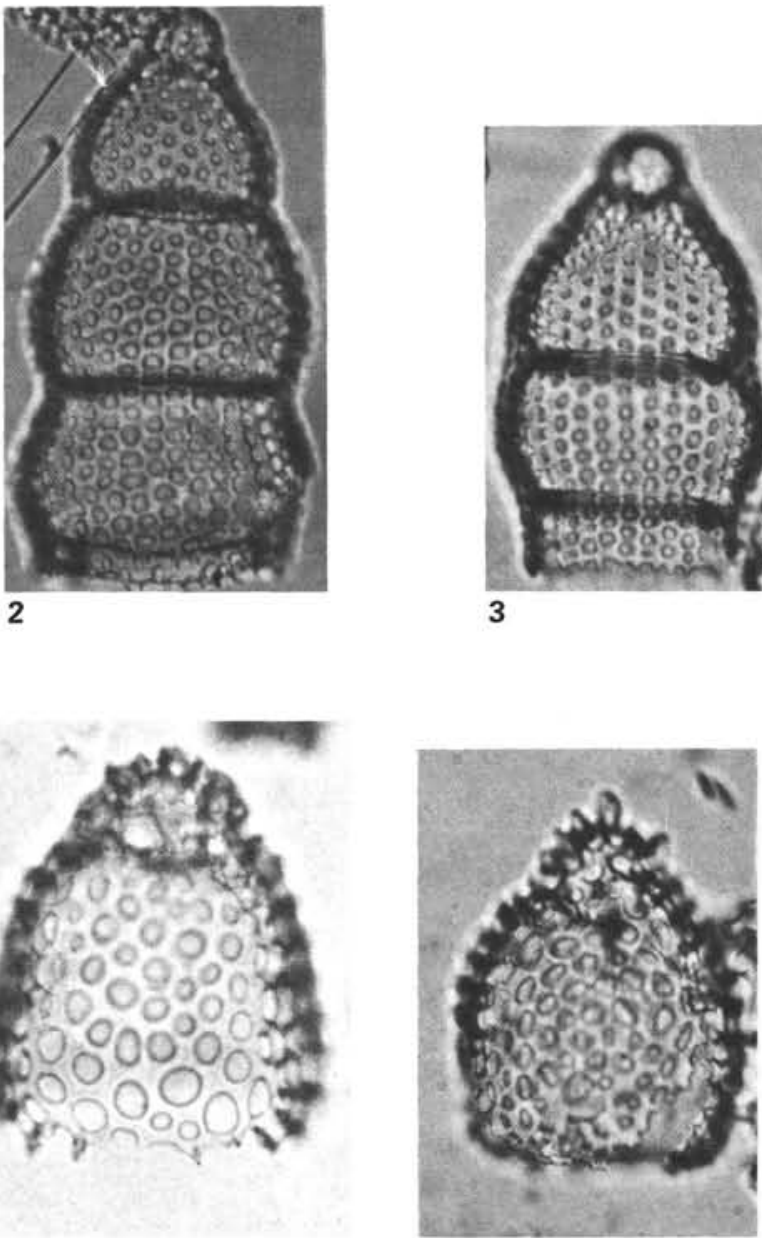

7

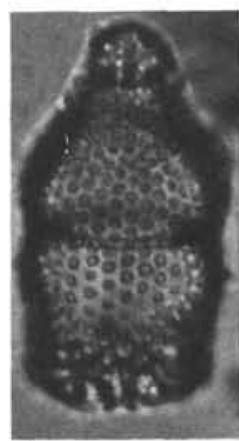

5

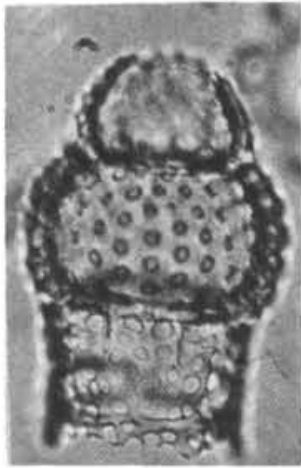

9

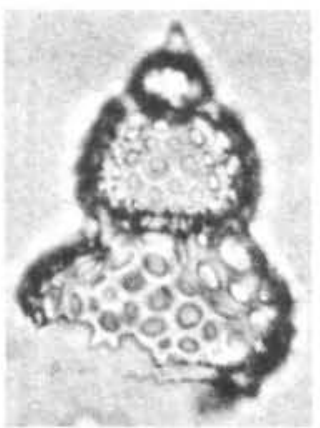

10

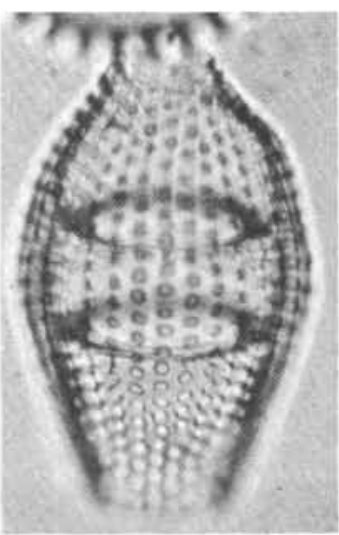

11

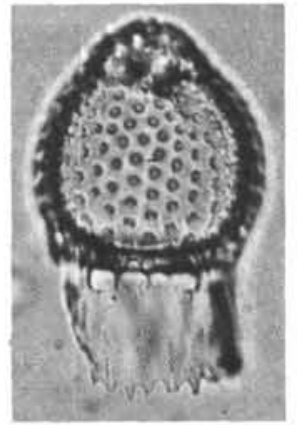

12

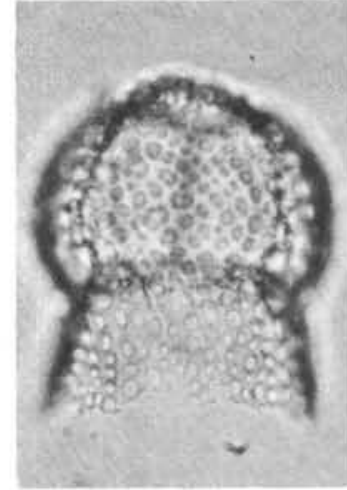

8

Plate 2. See note, Plate 1. 1. Phormocyrtis sp., Sample 515B-16-4, 22-24 cm, Sl. A, W38/0. 2. Eucyrtidium sp, Sample 515B-11-4, 58-60 cm, Sl. A, B46/0. 3-4. E. sp. cf. E. punctatum, (3) Sample 515B-11-4, 58-60, Sl. A, W55/4; (4) Sample 515B-8,CC, Sl. A, W58/3. 5. Lamprocyrtis sp., Sample 515B-21-4, 73-75 cm, Sl. A, E29/3. 6-7. Theoperid, gen. et ap. indet., (6) Sample 515B-17-3, 72-74 cm, Sl. A, K45/3, (7) Sample 515B-11-4, 58-60 cm, Sl. A, S46/2. 8. Artostrobid, gen. et sp. indet., 515B-8-4, 70-72 cm, Sl. A, O34/1. 9, 12. Sample 515B-11-4, 58-60 cm, (9) Stichocorys wolffii, Sl. A, W34/0, (12) Carpocanopsis bramlettei, Sl. A, S33/0. 10. E. diaphanes, Sample 515B-19-2, 74-76 cm, Sl. A, G55/4. 11. Podocyrtis sp., 515B-8-4, 70-72 cm, Sl. A, O35/2. 13. Carpocanistrum sp., 515B-10-2, 120-122 cm, Sl. A, C49/1. 